\title{
ДИНАМІКА ЗМІН БІОХІМІЧНИХ ПОКАЗНИКІВ КРОВІ ТА СТРУКТУР КІРКОВОЇ РЕЧОВИНИ НИРОК БІЛИХ ЩУРІВ ЗА УМОВ ТОКСИЧНОГО УРАЖЕННЯ ПЕЧІНКИ
}

Вступ. Високий рівень захворюваності на токсичні гепатити з розвитком поліорганної недостатності зумовлює актуальність дослідження змін біохімічних показників крові та з'ясування об'єктивних моророметричних змін структур нефронів, що характеризують морфоофункціональні зміни нирок при токсичному ураженні печінки.

Мета дослідження - вивчити динаміку змін біохімічних показників крові, а також морфологічних змін структур кіркової речовини нирок білих щурів за умов експериментального токсичного ураження печінки.

Методи дослідження. Експеримент виконано на 30-ти білих безпородних щурах-самцях, яких було поділено на 3 групи. Моделлю токсичного гепатиту слугувала інтоксикація тетрахлорметаном, який вводили через день внутрішньошлунково у вигляді 50 \% олійного розчину в дозі 2 г/кг маси тіла. Тривалість експерименту становила 2 і 14 діб. У крові визначали концентрацію загального білірубіну, сечовини, креатиніну, активність аланін- і аспартатамінотрансфераз. Для гістологічних досліджень забирали матеріал з кіркової речовини нирок, виготовляли гістологічні препарати і фрарбували їх гематоксиліном та еозином.

Результати й обговорення. У крові тварин з токсичним гепатитом на 2-гу і 14-ту доби проведення експерименту вміст загального білірубіну збільшувався у 2,4 та 3,2 раза. Підвищення активності внутрішньоклітинних ензимів аланін- і аспартатамінотрансфрераз у 9,5 та 17,4 i 14,1 та 7,3 раза у відповідні терміни експерименту вказувало на інтенсивне ушкодження клітин печінки. При цьому відзначено погіршення фрункціонального стану нирок, про що свідчило зростання концентрації сечовини у крові в 1,8 та 2,2 раза і креатиніну в 1,2 та 2,3 раза у відповідні терміни. Гістологічно у кірковій речовині нирок було виявлено ознаки порушення гемодинаміки, встановлено наявність ниркових тілець з ознаками як гіпертрофрії, так і гіпотрофії. їх співвідношення змінювалось протягом досліду. Водночас відбувалися звуження просвіту проксимальних звивистих канальців, зменшення площі їх епітеліоцитів та розвиток дистрофрічних змін. Відповідні параметри дистальних звивистих канальців зазнавали менш виражених змін.

Висновки. Токсичне ураження печінки викликало ушкодження клітинних мембран гепатоцитів, суттєво підвищувалась активність аланін-і аспартатамінотрансфрераз, загального білірубіну. Погіршувався функціональний стан нирок. Водночас встановлено зміни структурних компонентів кіркової речовини нирок на тлі гемодинамічних порушень.

КЛЮЧОВІ СЛОВА: токсичний гепатит; біохімічні показники крові; нирки; нефрон; морфологічні зміни.

ВСТУП. Сучасні наукові дослідження свідчать про те, що при токсичних гепатитах у результаті дії ксенобіотиків відбуваються порушення метаболічних процесів, що зумовлює зростання рівня різних токсичних продуктів їх розпаду, активізація процесів ліпопероксидації та окиснювальної модисрікації протеїнів оксидативного стресу в організмі й порушення антиоксидантної системи [1]. Дані процеси відіграють важливу роль в ушкодженні клітинних мембран, розвитку поліорганної патології [2, 3]. А печінка при цьому сама перетворюється на джерело ендогенної

(c) С. І. Яворська, Н. Є. Лісничук, Т. Я. Ярошенко, Б. Я. Ремінецький, І. М. Яворська-Скрабут, 2020. інтоксикації [4]. Відомо, що хронічне токсичне ураження печінки призводить до морфофрункціональних змін у нирках і розвитку гепаторенального синдрому [5]. Дослідженню структурної організації нирок у нормі та за умов поєднаних патологій присвячено ряд праць [6-8], проте ця тема залишається актуальною і потребує подальшого вивчення та отримання об'єктивних морфометричних даних.

Мета дослідження - вивчити динаміку змін біохімічних показників крові, а також морфологічних змін структур кіркової речовини нирок білих щурів за умов експериментального токсичного ураження печінки. 
МЕТОДИ ДОСЛІДЖЕННЯ. Досліди проведено на 30-ти білих безпородних щурах-самцях масою 160-170 г, яких утримували на стандартному раціоні віварію. Тварин поділили на 3 групи: 1-ша група (контрольна) складалася 3 10-ти білих щурів, яким імітували внутрішньошлункові введення, застосовуючи фрізрозчин, 2-га - 3 10-ти особин із змодельованим гострим токсичним ураженням печінки (тривалість спостереження - 2 доби), 3-тя - 3 10-ти щурів із зазначеною патологією, яких виводили з експерименту через 14 діб. Моделлю токсичного ураження тварин слугувала інтоксикація тетрахлорметаном, який вводили через день внутрішньошлунково у вигляді $50 \%$ олійного розчину в дозі 2 г/кг маси тіла щура. Виводили всіх тварин з експерименту за умов тіопентал-натрієвого знеболювання.

Усі маніпуляції зі щурами проводили, дотримуючись правил, передбачених положеннями Європейської конвенції про захист хребетних тварин, що використовуються для дослідних та інших наукових цілей (Страсбург, 1986), Загальних етичних принципів експериментів на тваринах, ухвалених на Першому національному конгресі з біоетики (Київ, 2001), Гельсінської декларації Генеральної асамблеї Всесвітньої медичної асоціації (2000).

У сироватці крові визначали концентрацію загального білірубіну, сечовини, креатиніну, активність аланінамінотранссрерази (АлАТ) і аспартатамінотрансферази (АсАТ), використовуючи напівавтоматичний біохімічний аналізатор "Нumalyzer 2000".

Для гістологічних досліджень матеріал кіркової речовини нирок фріксували $10 \%$ нейтральним фрормаліном i, після загальноприйнятої обробки та заливки у парафінові блоки, виготовляли гістологічні зрізи і фрарбували їх гематоксиліном та еозином. Гістологічні препарати вивчали задопомогою світлового мікроскопа "Seoscan", відеокамери "Vision CCD Camera" і програми InterVideoWinDVR. Морсометричні дослідження проведено за допомогою програм Відео Тест 5,0 KAAPA Image Base та Microsoft Exel на персо- нальному комп'ютері. Морфометрично визначали площу ниркових тілець, судинних клубочків, капсули Шумлянського - Боумена, діаметр проксимальних і дистальних звивистих канальців, площу їх епітеліоцитів [9]. Отриманий у результаті експерименту цифрровий матеріал було систематизовано й оброблено за допомогою методів варіаційної статистики з використанням критерію Стьюдента.

РЕЗУЛЬТАТИЙ ОБГОВОРЕННЯ. РеЗУЛЬТаТИ дослідження показали, що введення тетрахлорметану призводило до суттєвих змін біохімічних показників крові тварин експериментальних груп порівняно $з$ показниками контрольної групи (табл.). Спостерігали достовірне збільшення вмісту загального білірубіну в крові піддослідних тварин на 2-гу і 14-ту доби експерименту - у 2,4 та 3,2 раза. Водночас активність АлАТ і АсАТ підвищувалась у 9,5 та 17,4 і 14,1 та 7,3 раза у відповідні терміни. Суттєве зростання концентрації трансаміназ у крові експериментальних тварин вказувало на порушення фуункціональної активності й інтенсивне ушкодження клітин печінки.

Для оцінки фрункціонального стану нирок важливо визначити вміст креатиніну та сечовини у крові. У літературі звернуто увагу не лише на морфологічні аспекти, а й на зміни фуункціонального стану нирок при ураженні тетрахлорметаном, які проявляються зниженням величини кліренсу креатиніну, підвищенням екскреції осмотично активних речовин [7]. Збільшення вмісту сироваткового креатиніну $є$ одним із діагностичних критеріїв гепаторенального синдрому. Встановлено, що концентрація сечовини у крові на 2-гу і 14-ту доби досліду зростала в 1,8 та 2,2 раза відповідно. Концентрація сечовини як кінцевого продукту обміну протеїнів та основної складової частини залишкового азоту у ссавців залежить від інтенсивності її синтезу і виведення. Тому її визначення є важливим діагностичним тестом як для печінки, де вона синтезується, так і для нирок, через які виводиться [4]. Отримані дані можуть вказувати на посилення сечовино-

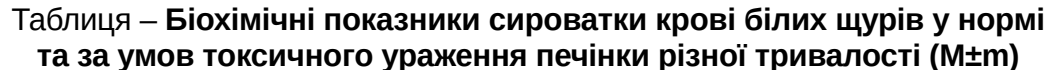

\begin{tabular}{||l|c|c|c||}
\hline \multirow{2}{*}{\multicolumn{1}{|c|}{ Показник }} & \multicolumn{3}{c||}{ Група тварин } \\
\cline { 2 - 4 } & \multirow{2}{*}{ контрольна } & \multicolumn{2}{c||}{ 3 токсичним гепатитом } \\
\cline { 2 - 4 } & & 2 доби & 14 діб \\
\hline АлАТ, мккат/л & $0,11 \pm 0,04$ & $1,05 \pm 0,03^{\star \star \star}$ & $1,91 \pm 0,03^{\star \star \star}$ \\
\hline АсАТ, мккат/л & $0,14 \pm 0,03$ & $1,98 \pm 0,04^{\star \star \star}$ & $10,21 \pm 0,52^{\star \star \star}$ \\
\hline Загальний білірубін, мкмоль/л & $3,23 \pm 0,16$ & $7,89 \pm 0,38^{\star \star \star}$ & $2^{\star \star}$ \\
\hline Сечовина, ммоль/л & $2,83 \pm 0,07$ & $5,02 \pm 0,31^{\star \star \star}$ & $140,09^{\star \star}$ \\
\hline Креатинін, мкмоль/л & $60,40 \pm 1,90$ & $72,31 \pm 1,82^{\star \star}$ & $140,20 \pm 3,93^{\star \star \star}$ \\
\hline
\end{tabular}

Примітка. Зірочкою позначено величини, які статистично достовірно відрізняються від аналогічних показників у контрольній групі тварин (** $\left.-p<0,01 ;{ }^{\star \star \star}-p<0,001\right)$. 
синтетичної функції печінки, а також на порушення видільної функції нирок. Визначення концентрації креатиніну в крові піддослідних тварин показали достовірне збільшення в 1,2 та 2,3 раза на 2-гу і 14-ту доби експерименту. Про ниркове походження гіперазотемії свідчить одночасне підвищення у крові концентрації сечовини і креатиніну, що могло стати наслідком зниження величини клубочкової фільтрації та порушення фрункціонального стану канальців нефрона $[3,7]$.

Результати гістологічних досліджень показали, що в нирках піддослідних тварин відбувався ряд морсоологічних змін на тлі порушення гемодинаміки. Саме сповільнення ниркового кровотоку може призводити до фрункціональних порушень нирок. У кірковій речовині нирок щурів 2-ї та 3-ї груп встановлено наявність ниркових тілець з ознаками як гіпертрофії, так і гіпотрофрії (рис. 1). Було проведено їх кількісний підрахунок, який показав, що на 2-гу добу кількість гіпертрофованих ниркових тілець становила 50,96 \%, а гіпотродованих - 49,04 \%. Площа перших ниркових тілець загалом зростала на $16,3 \%$ відносно контролю і становила $(6443,7 \pm 302,2)$ мкм $^{2}$ $(\mathrm{p}<0,001)$. Це відбувалося за рахунок збільшення площі судинних клубочків на $6,6 \%$ до $(4726,2 \pm 196,3)$ мкм² $^{2}(p<0,05)$ та площі просвіту капсули Шумлянського - Боумена на 55,1 \% до $(1717,5 \pm 85,9)$ мкм² $^{2}(p<0,001)$. Капілярна сітка судинних клубочків мала ознаки повнокров'я та набряку їх ендотелію. Площа інших ниркових тілець зменшувалася на $11,4 \%$ до $(4907,5 \pm 215,4)$ мкм $^{2}$ $(\mathrm{p}<0,05)$ в результаті зменшення площі судинного клубочка на 20,4 \% до $(3525,6 \pm 146,3)$ мкм² $^{2}$ $(\mathrm{p}<0,01)$. Водночас площа просвіту капсули Шумлянського - Боумена збільшувалася на 24,7 \% до $(1381,5 \pm 69,1)$ мкм $^{2}(p<0,05)$.

При цьому слід зазначити, що зміни у канальцевій частині нефрона часто більш виражені, ніж у клубочковій. Ступінь ураження змінених діля-

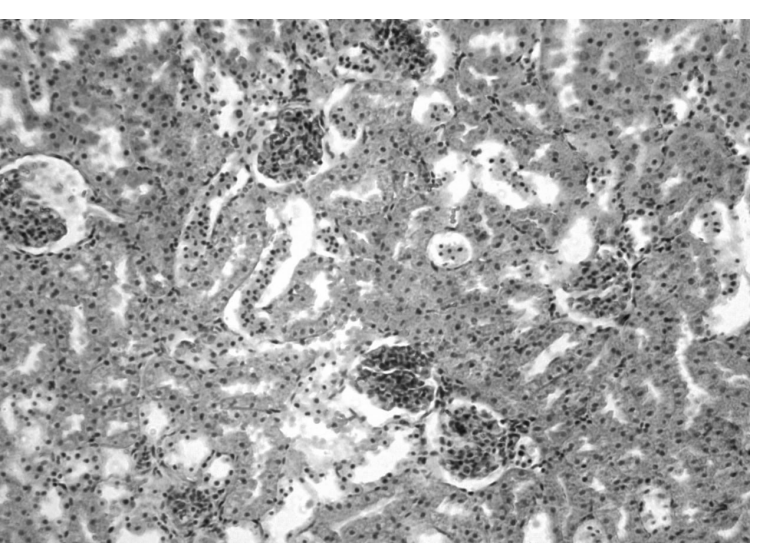

Рис. 1. Фрагмент кіркової речовини нирки тварини на 2-гу добу токсичного ураження печінки. Гіпер- та гіпотрофовані ниркові тільця, повнокров'я судин. Помірний набряк строми. Забарвлення гематоксиліном та еозином. ×200. нок неоднаковий у різних відділах канальців, що можна пояснити морфоорункціональними особливостями різних відділів несррона. На 2-гу добу досліду морфометрично встановлено звуження просвіту проксимальних звивистих канальців на $29,1 \%$ до $(15,20 \pm 0,63)$ мкм $(p<0,01)$, яке супроводжувалось збільшенням площі епітеліоцитів проксимального відділу нефрона на 5,5 \% до $(155,3 \pm 6,6)$ мкм $^{2}(p<0,05)$. Морфометрично виявлено тенденцію до менш вираженого звуження просвіту дистальних звивистих канальців 3 одночасним зменшенням площі клітин на $7,2 \%$ до $(101,0 \pm 2,8)$ мкм² $^{2}$.

На 14-ту добу експерименту змінювалося співвідношення кількості гіпер- і гіпотросрованих ниркових тілець на користь перших - 57,6 та 42,4 \% відповідно. При цьому морфометрично встановлено, що площа гіпертрофованих ниркових тілець збільшувалася на 19,9 \% до $(6645,7 \pm 310,0)$ мкм $^{2}(p<0,001)$ за рахунок зростання площі судинного клубочка на 13,6 \% $(p<0,01)$ та площі просвіту капсули Шумлянського - Боумена на 45,4 \% ( $<<0,001)$. Площа гіпотрофованих ниркових тілець зменшувалася на $15,1 \%$ до $(4706,9 \pm 205,9)$ мкм $^{2}(p<0,05)$, в основному через зменшення площі судинного клубочка на $19,7 \%$ до $(3559,2 \pm 145,8)$ мкм $^{2}(p<0,01)$, при цьому на 3,5 \% недостовірно зростала площа просвіту капсули. В інтерстиційній тканині виявлено помірний набряк, лімсрогістіоцитарну інфрільтрацію елементів строми. Спостерігали паретичне розширення гемокапілярів (рис. 2). Також встановлено істотне звуження просвіту проксимальних звивистих канальців - на 33,2 \% $(p<0,01)$, при цьому площа їх епітеліоцитів зменшувалася на 5,9 \% $(p<0,05)$. Результати світлооптичних досліджень засвідчили, що розміри дистальних звивистих канальців зазнавали менш виражених змін. Морфометрично встановлено несуттєве зменшення діаметра їх просвіту.

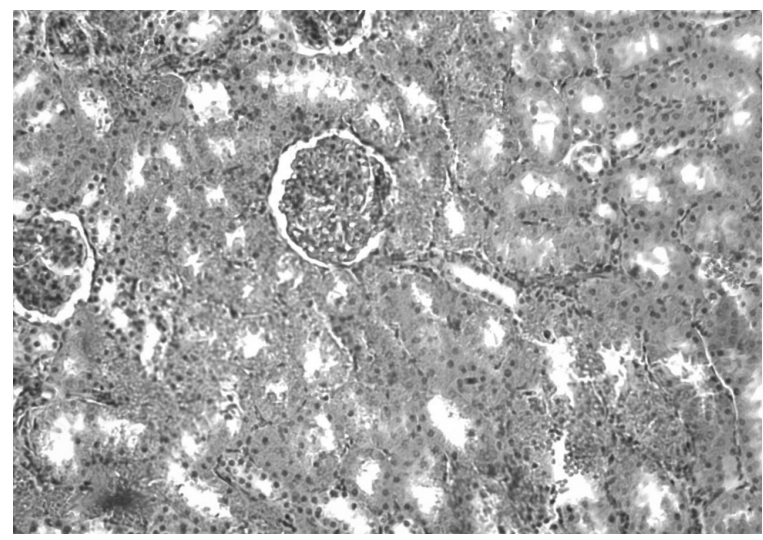

Рис. 2. Фрагмент кіркової речовини нирки тварини на 14-ту добу токсичного ураження печінки. Звуження просвіту проксимальних звивистих канальців, помірний набряк, дрібні екстравазати. Забарвлення гематоксиліном та еозином. ×200. 
А в епітелії проксимальних і дистальних канальців при цьому спостерігали деструктивні зміни.

ВИСНОВКИ. Токсичне ураження печінки викликало ушкодження клітинних мембран гепатоцитів, суттєво підвищувалась активність аланін- і аспартатамінотранссераз, загального білірубіну. Погіршувався ффункціональний стан нирок. Водночас встановлено зміни структурних компонентів кіркової речовини нирок на тлі гемодинамічних порушень. Під час якісних і кількісних досліджень встановлено пристосувально-компенсаторну перебудову структур нефронів, дистрофічні зміни епітелію канальцевої системи, більше виражені в проксимальних звивистих канальцях. Виявлені біохімічні та морфрологічні зміни свідчать про порушення сечоутворення.

\section{СПИСОК ЛІТЕРАТУРИ}

1. Никифорук А. Я. Дослідження антиоксидантних властивостей екстракту зі шпинату городнього листя на моделі тетрахлорметанового ураження печінки / А. Я. Никифорук, Л. С. Фіра, П. Г. Лихацький // Мед. та клініч. хімія. - 2018. - 20, № 4 (77). - С. 36-43.

2. Гепатотоксичність ліків / Р. Ю. Грицко, А. М. Задорожний, О. Б. Герасун [та ін.] // Гепатологія. -2014. № 2. - С. 17-28.

3. Лопаткина Т. Н. Поражение почек при хронических заболеваниях печени / Т. Н. Лопаткина, Т. Н. Краснова // Клинич. гепатология. -2016. - № 3. C. $15-21$.

4. Галенова Т. І. Зміна біохімічного профрілю організму за умов тетрахлорметан-індукованого ураження печінки у щурів / Т. І. Галенова, Н. Г. Ракша, О. М. Савчук // Scientific Journal "ScienceRise: Biological Science". - 2016. - № 2 (2). - C. 47-54.

\section{REFERENCES}

1. Nykyforuk, A., Fira, L., \& Lykhatskyi, P. (2018). Doslidzhennia antyoksydantnykh vlastyvostei ekstraktu zi shpynatu horodnoho lystia na modeli tetrakhlormetanovoho urazhennia pechinky [Investigation of antioxidant properties of spinach leaf extract on the model of carbon tetrachloride liver damage]. Med. i kiln. khim. - Medical and Clinical Chemistry, 20, 4, 36-43 [in Ukrainian].

2. Hrytsko, A., Zadorozhnyi, O., \& Herasun, R. (2014). Hepatotoksychnist likiv [Hepatotoxicity of drugs]. Hepatolohiia - Hepatology, 2, 17-28 [in Ukrainian].

3. Lopatkyna, T., \& Krasnova, T. (2016). Porazhenie pochek pri khronicheskikh zabolivaniyakh pecheni [Kidney damage in chronic liver disease]. Klin. gepatologiya Clinical Hepatology, 3, 15-21 [in Russian].

4. Halenova, T., Raksha, N., \& Savchuk, O. (2016). Zmina biokhimichnoho profiliu orhanizmu za umov tetrakhlormetan-indukovanoho urazhennia pechinky u shchuriv [Change in the biochemical profile of the organism under conditions of tetachloromethane-induced liver damage in rats]. Scientific Journal "ScienceRise: Biological Science", 2 (2), 47-54 [in Ukrainian].
5. Рикало Н. А. Структурні зміни епітеліального та клубочкового компонентів нирок щурів при моделюванні хронічного токсичного гепатиту та корекції лізиноприлом / Н. А. Рикало, Ю. М. Береговенко // Актуальные проблемы транспортной медицины. 2017. - № 2 (48). - С. 104-109.

6. Морфологічна характеристика ниркових тілець у щурів / А. А. Капустянська, Ю. Б. Чайковський, В. І. Шепітько [та ін.] // Світ медицини та біології. 2018. - № 2 (64). - С. 145-147.

7. Функціональний нирковий резерв : монограсрія / [А. І. Гоженко, А. В. Кравчук, О. П. Никитенко та ін.]. Одеса : Фенікс, 2015. - 182 с.

8. Wong F. The evolving concept of acute kidney injury in patients with cirrhosis / F. Wong // Nat. Rev. Gastroenterol. Hepatol. - 2015. - 12. - P. 711-719.

9. Автандилов Г. Г. Основы количественной патологической анатомии / Г. Г. Автандилов. - М. : Медицина, 2002. - 240 с.

5. Rykalo, N., \& Berehovenko, Yu. (2017). Strukturni zminy epitelialnoho ta klubochkovoho komponentiv nyrok shchuriv pry modeliuvanni khronichnoho toksychnoho hepatytu ta korektsii lizynoprylom [Structural changes of epithelial and glomerular components of rat kidneys in modeling of chronic toxic hepatitis and correction by lysinopril]. Aktualnye prob. transport. med. - Current Problems of Transport Medicine, 2 (48), 104-109 [in Ukrainian].

6. Kapustianska, A., Chaikovskyi, Yu., \& Shepitko, V. (2018). Morphological characteristics of renal corpuscles in rats. The World of Medicine and Biology, 2 (64), 145147 [in Ukrainian].

7. Hozhenko, A., Kravchuk, A., Nykytenko, O., Moskolenko, O., \& Sirman, V. (2015). Funktsionalnyi nyrkovyi reserve: monohrafiia [Functional renal reserve: monography]. Odesa: Feniks [in Ukrainian].

8. Wong, F. (2015). The evolving concept of acute kidney injury in patients with cirrhosis Nat. Rev. Gastroenterol. Hepatol., 12, 711-719.

9. Avtandilov, G. (2002). Osnovy kolichestvennoy patologicheskoy anatomii [Fundamentals of quantitative pathological anatomy]. Moscow: Meditsina [in Russian]. 


\title{
ДИНАМИКА ИЗМЕНЕНИЙ БИОХИМИЧЕСКИХ ПОКАЗАТЕЛЕЙ КРОВИ И СТРУКТУР КОРКОВОГО ВЕЩЕСТВА ПОЧЕК БЕЛЫХ КРЫС В УСЛОВИЯХ ТОКСИЧЕСКОГО ПОРАЖЕНИЯ ПЕЧЕНИ
}

\begin{abstract}
Резюме
Вступление. Высокий уровень заболеваемости токсическими гепатитами с развитием полиорганной недостаточности обусловливает актуальность исследования изменений биохимических показателей крови и выяснения объективных морфометрических изменений структур нефронов, которые характеризуют морфофрункциональные изменения почек при токсическом поражении печени.

Цель исследования - изучить динамику изменений биохимических показателей крови, а также морфологических изменений структур коркового вещества почек белых крыс в условиях экспериментального токсического поражения печени.

Методы исследования. Эксперимент выполнен на 30-ти белых беспородных крысах-самцах, которые были разделены на 3 группы. Моделью токсического гепатита служила интоксикация тетрахлорметаном, который вводили через день внутрижелудочно в виде 50 \% масляного раствора в дозе 2 г/кг массы тела. Длительность эксперимента составила 2 и 14 суток. В крови определяли концентрацию общего билирубина, мочевины, креатинина, активность аланин- и аспартатаминотрансфераз. Для гистологических исследований забирали материал из коркового вещества почек, изготавливали гистологические препараты и окрашивали их гематоксилином и эозином.
\end{abstract}

Результаты и обсуждение. В крови животных с токсическим гепатитом на 2-е и 14-е сутки проведения эксперимента содержание общего билирубина увеличивалось в 2,4 и 3,2 раза. Повышение активности внутриклеточных энзимов аланин- и аспартатаминотрансфрераз в 9,5 и 17,4, 14,1 и 7,3 раза в соответствующие сроки эксперимента указывало на интенсивное повреждение клеток печени. При этом отмечено ухудшение фуннционального состояния почек, о чем свидетельствовало возрастание концентрации мочевины в крови в 1,8 и 2,2 раза и креатинина в 1,2 и 2,3 раза в соответствующие сроки. Гистологически в корковом веществе почек было выявлено признаки нарушения гемодинамики, установлено наличие почечных телец с признаками как гипертрофрии, так и гипотрофии. Их соотношение изменялось в течение опыта. В то же время происходили сужение просвета проксимальных извилистых канальцев, уменьшение площади их эпителиоцитов и развитие дистрофических изменений. Соответствующие параметры дистальных извилистых канальцев изменялись менее выражено.

Выводы. Токсическое поражение печени вызвало повреждение клеточных мембран гепатоцитов, существенно повышалась активность аланин- и аспартатаминотрансорераз, общего билирубина. Ухудшалось фрункциональное состояние почек. В то же время установлено изменения структурных компонентов коркового вещества почек на фоне гемодинамических нарушений.

КЛЮЧЕВЫЕ СЛОВА: токсический гепатит; биохимические показатели крови; почки; нефрон; морфологические изменения.

S. I. Yavorska, N. Ye. Lisnychuk, T. Ya. Yaroshenko, B. Ya. Reminetskyy, I. M. Yavorska-Skrabut I. HORBACHEVSKY TERNOPIL NATIONAL MEDICAL UNIVERSITY

\section{DYNAMICS OF CHANGES IN BIOCHEMICAL INDICATORS OF BLOOD AND STRUCTURES OF RENAL CORTEX OF WHITE RATS UNDER CONDITIONS OF TOXIC LIVER INJURY}

\section{Summary}

Introduction. The high incidence of toxic hepatitis with the development of multiple organ failure determines the relevance of the study of changes in blood biochemical parameters and elucidation of objective morphometric changes in nephron structures that characterize morphofunctional changes in the kidneys in toxic liver damage.

The aim of the study - to learn the dynamics of changes in the biochemical parameters of blood as well as morphological changes in the structures of the cortical substance of the kidneys of white rats under conditions of experimental toxic liver injury. 
Research Methods. The experiments were performed on 30 white male rats, which were divided into 3 groups. The model of toxic hepatitis was intoxication with carbon tetrachloride, which was administered intragastrically every other day in the form of $50 \%$ oil solution at a dose of $2 \mathrm{~g} / \mathrm{kg}$ body weight. Duration of the experiment -2 and 14 days. The concentrations of total bilirubin, urea, creatinine, aspartate and alanamine aminotransferase activity were determined in blood. For histological examinations, material was taken from the renal cortex, histological preparations were made and stained with hematoxylin and eosin.

Results and Discussion. It was found that in the blood of animals with toxic hepatitis on the 2nd and 14th day of the experiment there was an increase in total bilirubin in 2.4 and 3.2 times. The increase in the activity of intracellular enzymes ALT and AST in 9.5 and 17.4 times and 14.1 and 7.3 times in the corresponding terms of the experiment indicated intense damage of hepatocytes. At the same time, deterioration of the functional state of the kidneys was noted, evidenced by an increase in the concentration of urea in blood by 1.8 and 2.2 times and creatinine by 1.2 and 2.3 times in the respective terms. Histologically in the cortical substance of the kidneys were found signs of hemodynamic disorders, the presence of renal corpuscles with signs of hypertrophy and hypotrophy. Their ratio changed during the experiment. At the same time, there were a narrowing of the lumen of the proximal convoluted tubules, a decrease in the area of their epitheliocytes and the development of dystrophic changes. The corresponding parameters of the distal convoluted tubules underwent less prominent changes.

Conclusion. Toxic liver injury caused damage of the cell membranes of hepatocytes, there was a significant increase in the activity of ALT and AST, total bilirubin. The functional state of the kidneys has deteriorated. At the same time, changes in the structural components of the renal cortex on the background of hemodynamic disorders were found.

KEY WORDS: toxic hepatitis; biochemical parameters of blood; kidney; nephron; morphological changes.

Отримано 16.04.20

Адреса для листування: С. І. Яворська, Тернопільський національний медичний університет імені І. Я. Горбачевського мОз Украӥни, майдан Волі, 1, Тернопіль, 46001, Україна, e-mail: yavorska@tdmu.edu.ua. 